\title{
XPOHИKA
}

\section{КОНФЕРЕНЦИЯ ПО ЭЛЕКТРИЧЕСКИМ МЕТОДАМ ОБРАБОТКИ ПИЩЕВЫХ ПРОДУКТОВ}

С 7 по 13 октября 1958 г. в г. Киеве была проведена конференция по электрическим методам обработки пищевых продуктов, органнзованная Киевским технологическим институтом пищевой промышленности УССР.

Широкий круг вопросов, охваченных программой работы конференции, и новизна тематики вызвали большой интерес со стороны работников науки и промышленности. 60 городов СССР были представлены 350 делегатами, из которых 119 человек были направлены высшими учебными заведениями и научно-исследовательскими организациями.

$\mathrm{Ha}$ заседаниях конференции были заслушаны и подверглись обсуждению более 50 докладов и сообшений, освещающих -вопросы применения для обработки пищевого сырья и продуктов электростатического поля, постоянного тока и тока низкой частоты, токов высокой частоты, инфракрасных и ультрафиолетовых излучений, рентгеновских и гамма лучей. Дополнительно были сделаны сообщения, относящиеся к применению ультразвуковых колебаннй в люиевой промышленности,

Значительное внимание уделялось вопросам применения для технологических целей токов высокой частоты (ТВЧ), в особенности обработке непроводниковых материалтов в электрическом поле высокой частоты. На эту тему было заслушано свыше 20 докладов и сообщений, в ко горых освещались вопросы теоретического и технологиче"кого характера. Так, например: «Электрическне свойства некоторых пищевых продуктов в полях высокой частоты» (Андреев С. Н., Кудин В. Н., Нетушил А. В. - Москва); «Активные потери в пище̨ых продуктах» (Павлов И. С. - Киев); «Электрические свойства молока» (Недзвецкий Ю. Э.Ленинград); «Непрерывно действуюшцй автоматпческий высокочастотный стерілнзатор для поточной стеритизацни плодоягодных консервов» (Черняев Н. Д.Москва); «Дефростация килькі токами высокой частоты» (Подсевалов В. Н.Астрахань); «Высокочастотнал проварка рыбы горячего электрокопчения» (Калитины А. А. и М. И. и Павлов И. С.Киев); «Особенности технологии производства колбасных изделий при обработке их токами высокой частоты» (Шишкина Н. Н. - Москва) и др.

Из докладов на прочие темы большой интерес и широкий обмен мнениями вызвали следующие: «Применение инфракрасного нагрева для сушки в производстве кондитерских изделий» (Белостоцкпй Н. Б. - Рига); «Технологические обоснования процесса горячего электрокопчения рыбы» (Қалитины М. И. и А. А., Наумова Е. П. - Киев); «Новая технология рыбы и производства сардин и шпрот с применением инфракрасных лучей и коптильной жидкости» (Лапшин И. И. - Москва); «Экспериментальная установка ВНИИҚОП для ионизационной обработки пицевых продуктов» (Черняев Н. Д. - Москва); «Исследование возможностей применения радноактивных излучений для консервации белкового остатка покровного сала китов» (Цыпкин С. И. - Ленинград) и др.

Содержание большей части прочитанных на конференции докладов указывает на большую творческую работу в области электрической обработки пищевых продуктов, проводимую в большинстве случаев на высоком теоретическом уровне как отдельными лицами, так и коллективами научных и производственных работников нашей страны, if на актуаль. ность внедрения электротехнологии в ряд областей пицевой промышленности.

Наряду с этнм следует констатнровать, что темы некоторых докладов (например, по вопросам сушки в поле токов высокой частоты), помимо отсутствия новизны, представляли сомнительную теоретическую и практическую ценность.

Совершенно не рассматривались на конференции вопросы гигиены труда, экранирования установок и помещениі,, борьбы с радиопомехами, что может создать представление о нереальной упроценности внедрения некоторых процессOв в пронзводство. 
В результате широкой дискуссиі и обмена мнениями в докладах и выступлениях, конференция выработала ряд решений, направ.тенных на дальнейшее развитие работ в об.ласти применения электрических методов при обработке пицевых продуктов и віедрение нх в промынленность. Существеннейшими из них следует считать намечающиеся мероприятпя по координированию и дальнейшему развитию работ в области электротехнологин, внедрению уже разработанных технологических процессов, созданию типовых проектов и аппаратуры, расширению пропаганды использования электрических

\section{Поступнла в редакцию} 3 XI 1958 r. методов в пищевой промышленности путем періодического созыва конференций " совецаний, а также выпуска научной, технической, пернодической и справочной .литературы.

Итоги Первой Всесоюзной конференции по э.тектрпческим методам обработки пищевых продуктов показали большой ннтерес $\mathrm{k}$ новой технике со стороны научных и технических работников пищевой гіромышленности. Конференция, несомненно, является положительным фактором в тете развития этой отрасли элек тротехнотогни.

В. В. Вологдин

.Тенннградский электротехнический институт им. В. И. Ульянова (Ленина) 